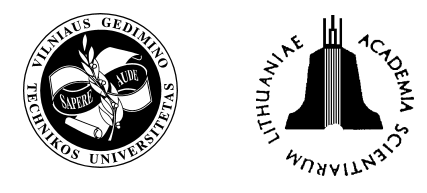

\title{
RESILIENT BEHAVIOUR OF HOT MIXED AND CRACK SEALED ASPHALT CONCRETE UNDER REPEATED LOADING
}

\author{
Hassan Ziari', Mahmud Ameri², Mohammad Mahdi Khabiri ${ }^{3}$ \\ ${ }^{1,2,3}$ Dept of Civil Engineering, Iran Science and Technology University, Iran \\ E-mail: ${ }^{3}$ Khabiri@iust.ac.ir
}

Received 2 October 2006; accepted 15 February 2007

\begin{abstract}
Bituminous mixes are becoming increasingly important in the road industry. The road engineers identify rutting as a major source of distress in Hot Mix Asphalt (HMA) pavements. The Asphalt Mix Design Marshal method adequately addresses the aggregate and asphalt binder properties that contribute to permanent deformation. However, there is no laboratory test currently at hand to quickly predict permanent deformation susceptibility of HMA. The main purpose of this paper is to provide practical information of laboratory samples for practitioners and mix designers. Thus, relevant test procedures and results of tests conducted are reported in this paper. Two resilient behaviours of cracked sealed asphalt concrete were studied by varying temperature and time of loading to understand the crack sealed pavement behaviour under Iran conditions.
\end{abstract}

Keywords: permanent deformation, Marshal method, hot mix asphalt (HMA), rutting, strain, cracked sealed.

\section{Introduction}

Permanent deformation, physically visible as ruts on the pavement surface, is a primary concern of asphalt mix designers, materials engineers, contractors, and highway agencies [1]. Quality of hot mix asphalt (HMA) is one of the main factors that affects the flexible pavement performance. Surface rutting in excess of about $6 \mathrm{~mm}$ is typically considered to be a hydroplaning safety hazard. As a result, excessive rutting is often responsible for premature maintenance and rehabilitation activities, reducing the service life of the pavement $[2,3]$.

The ability to predict the amount and growth of permanent deformation or rutting in flexible pavements is an important aspect of pavement design. The evaluation of asphalt concrete mixes for their tendency to rutting has been an important research field for many years. This mode of distress is the result of consolidation of the mix after construction and plastic flow of the HMA in the wheel path over time and is a primary cause of much of the rutting observed on the roadway $[4,5]$. Excessive asphalt cement content, excessive fine grained aggregate and high percentages of natural, rounded aggregate particles are considered to be common material-related causes of permanent deformation [6]. The HMA mixture design and analysis system does not presently specify a prooftest to assess the relative rutting susceptibility of HMA. Such a test is desirable to enable the design of a mix in the laboratory with a significant degree of confidence that the mix will not fail on the roadway due to permanent deformation. It is attempted to measure the permanent deformation (as indicator of rutting in asphalt) for the different percentages of bitumen and temperatures by device UTM-5.

The primary objectives of this study are to develop the Laboratory Testing Method to simulate the laboratory testing of asphalt mixes for rutting and to relate the test results to basic material properties.

\section{Literature review}

Bituminous sealants have been used to seal pavement cracks and joints for more than 60 years. They reduce the ingress of water into the pavement structure and help reduce the rate of pavement degradation and rutting. However, it was not until the 1960 's, after the pioneering work of Tons on sealant mechanics, that sealants showed significant benefits and allowed for extending the service life of roadways where they were applied. A recent work with laboratory analysis demonstrates the great advances in this field.

In this section, the scientific principles are emphasised 
more than other subject, because the principles are very important.

Rutting is caused by densification when voids become filled, and shear deformation or plastic flow in a bituminous mix. The air void content in a mix must be controlled to accommodate traffic densification. Large stone mixes can reduce rutting, due to the bridging effect to stone on stone. With larger particle sizes in a mix, the total surface area of aggregate is less and binder content can be lower.

Asphalt creep deformation $\left(\varepsilon_{t}\right)$ can be resolved into four recoverable and irrecoverable components [7].

$$
\varepsilon_{t}=\varepsilon_{e}+\varepsilon_{p l}+\varepsilon_{v e}+\varepsilon_{v p l},
$$

where $\varepsilon_{e}$ is the elastic strain, $\varepsilon_{p l}$-the plastic strain, $\varepsilon_{v e}-$ the visco-elastic strain, and the visco-plastic strain. $\varepsilon_{v e}$ and $\varepsilon_{v p l}$ occur during loading. Once the $\varepsilon_{e}$ is removed, $\varepsilon_{v e}$ is recovered instantaneously, and $\varepsilon_{v e}$ is recovered after the rebound period $[8,9]$.

As shown in Fig 1, there are 3 primary stages in the life cycle of a mix under repeated loading before failure. During the primary stage, the rate of deformation is high but it decreases. In the secondary stage, the deformation rate is regarded as being constant while deformation increases steadily. And in the tertiary stage, deformation increases rapidly, till failure occurs.

An important parameter quantifying mix performance is the creep stiffness of the accumulated strain $\left(\mu_{\varepsilon}\right)$ versus pulse count curve (as in Fig 2). An acceptable creep stiffness for mixes subjected to dynamic creep loading is a slope between 2 and 10 for medium trafficked pavements (between 2000 and $100 \mathrm{EAL} / \mathrm{Lane} / \mathrm{Day})$ for WMAPT of 10 to $20{ }^{\circ} \mathrm{C}[8]$.

Irrecoverable (permanent) strain or visco-plastic strain $\left(\varepsilon_{p}\right)$ is important when evaluating potential and the applied stress $(\sigma)$ are used to calculate creep modulus $\left(E_{c}\right)$ of a mix from:

$$
E_{c}=\frac{\sigma}{\varepsilon_{p}} .
$$

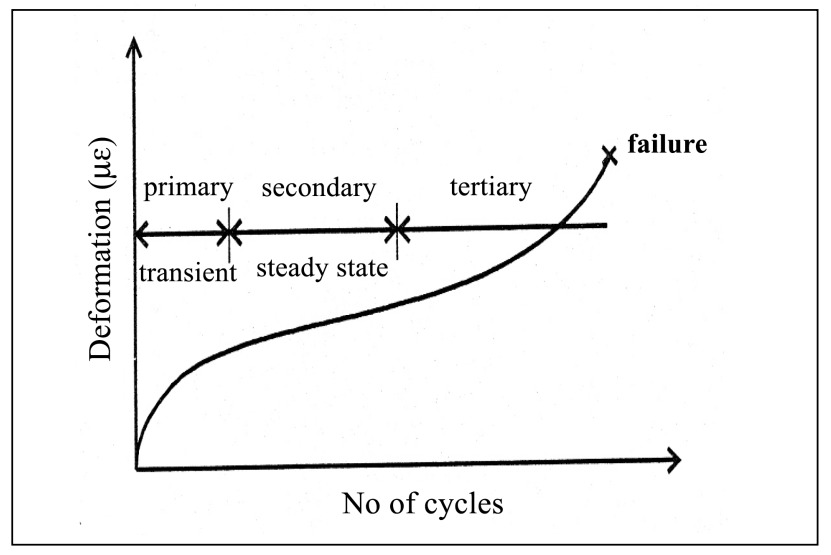

Fig 1. Performance of a typical mix specimen

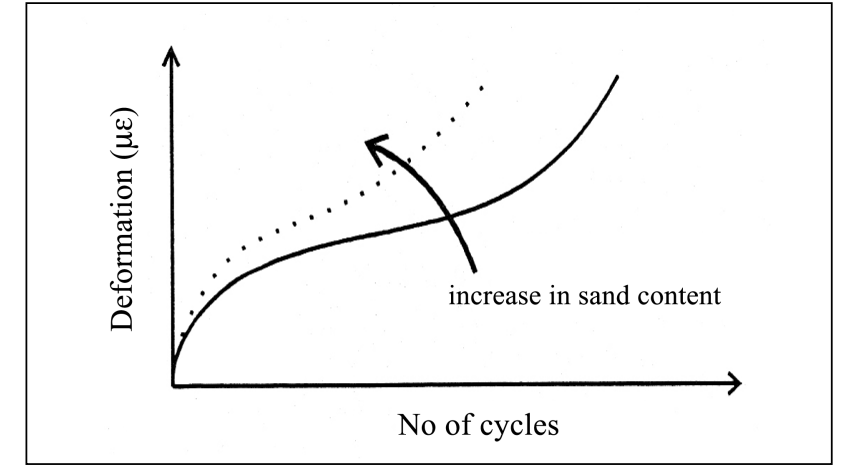

Fig 2. Permanent deformation of a mix

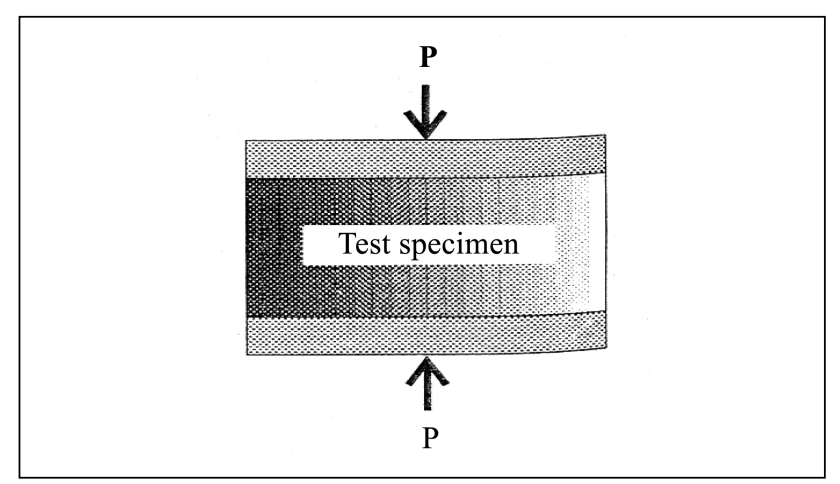

Fig 3. Specimen setup for permanent compressive strain test

Permanent creep testing at realistic temperatures and stress levels in the field is sensitive to asphalt gradation, binder content, aggregate type, air void, temperature and stress state.

Feedback Controlled Repeated Uniaxial Loading Strain Test software was used to determine permanent compressive strain with mix specimen's setup as shown in Fig 3. Normally, specimens created for each mix type are tested at $50{ }^{\circ} \mathrm{C}$.

\section{Experimental methodology and results}

Two series of tests were done. The variable in the first series of laboratory tests - compacted specimens was bitumen content, for determining the effect of variations in bitumen content within the allowed envelope of the Iran mix specification. The second series involved creep testing (at different temperatures) in a bituminous mix. Aggregate for all the specimens came from the stockpile of crushed river gravel of Tehran. These tests have been developed for cracked and crack sealant HMA.

ASTM code specifies that from a sample of coarse aggregate not less than $98 \%$ of the particles shall have one broken face and $60 \%$ of them two or more broken faces; for the aggregate tested, $98 \%$ of the particles had two or more broken faces. Sieve analyses of the aggregate were done according to ASTM 4402-1986 for determining the particle size distribution [9]. 
The particle size distributions are presented in Table 1 and Fig 4.

Penetration grade of bitumen was used, 60/70 (ASTMD5).

Bitumen and aggregate were normally mixed together in accordance with ASTM 2891.2.1-1994. For each mix combination, samples were prepared and compacted following ASTM, unless otherwise noted [9].

Some of the critical aggregate and binder properties of the mixes included in this study are summarised in Table 2. These include: binder content; and whether. Comparisons

Table 1. Aggregate gradations for all test series

\begin{tabular}{|c|c|}
\hline Sieve size $(\mathrm{mm})$ & $\begin{array}{c}\text { Percentage of aggregate particles } \\
\text { passing each sieve }\end{array}$ \\
\hline 37,500 & 100 \\
\hline 19,000 & 84 \\
\hline 6,700 & 53 \\
\hline 2,360 & 34 \\
\hline 1,180 & 26 \\
\hline 0,600 & 20 \\
\hline 0,300 & 17 \\
\hline 0,150 & 12 \\
\hline 0,075 & 6 \\
\hline
\end{tabular}

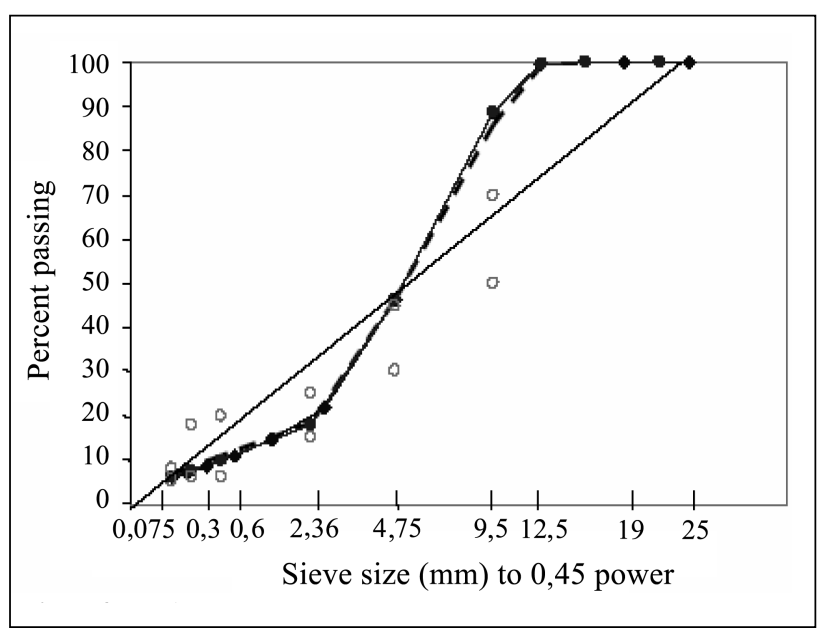

Fig 4. Aggregate gradations for all test series (up-limit and downlimit)

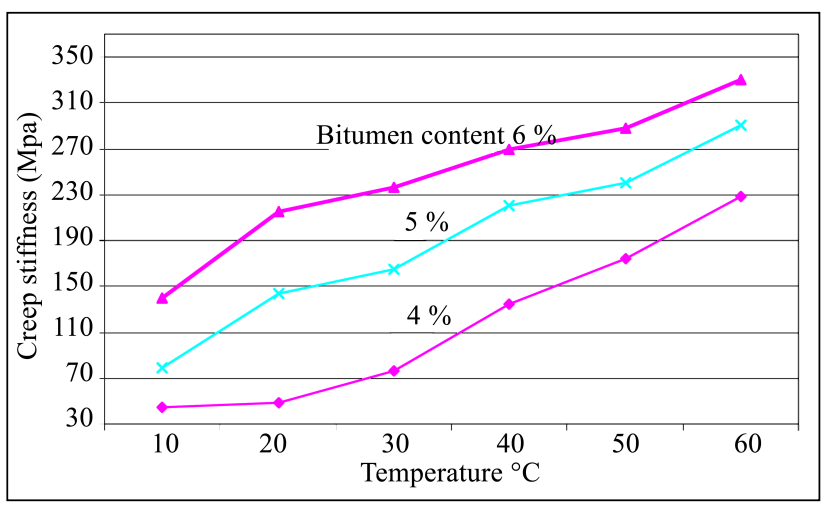

Fig 5. Effect of bitumen content and temperature on creep stiffness of the observed UTM-5 rut depths versus the above-referenced aggregate, binder properties and temperature are presented in the following paragraphs.

$60-70 \%$ of bitumen was used as the binder. Tests were done with a load of $5 \mathrm{KN}$. Permanent deformation (creep) tests were conducts at $10-60{ }^{\circ} \mathrm{C}$. Constituent properties and creep test results are ummarised in Table 2 [10].

As it was expected, temperature had the greatest impact on mix permanent deformation (Figs 5, 6). Higher bitumen content results in a more flexible pavement mix which is more prone to rutting, particularly at high temperatures,

Table 2. Mix properties and test results [10]

\begin{tabular}{|c|c|c|c|c|}
\hline \multicolumn{2}{|c|}{ Binder content (\%) } & 4 & 5 & 6 \\
\hline \multicolumn{2}{|c|}{ Bulk density $\left(t / m^{3}\right)$} & 1,91 & 1,95 & 1,89 \\
\hline Air voids (\%) & Test Tem & 3,5 & 5 & 5,3 \\
\hline $\begin{array}{l}\text { Creep stiffness } \\
\text { (Mpa) }\end{array}$ & \multirow{2}{*}{$10{ }^{\circ} \mathrm{C}$} & 45 & 140 & 79 \\
\hline $\begin{array}{l}\text { Accumulated } \\
\text { strain }\end{array}$ & & 2468 & 3325 & 4389 \\
\hline $\begin{array}{l}\text { Creep stiffness } \\
\text { (Mpa) }\end{array}$ & \multirow{2}{*}{$20{ }^{\circ} \mathrm{C}$} & 95 & 215 & 144 \\
\hline $\begin{array}{l}\text { Accumulated } \\
\text { strain }\end{array}$ & & 2945 & 3844 & 4719 \\
\hline $\begin{array}{l}\text { Creep stiffness } \\
\text { (Mpa) }\end{array}$ & \multirow{2}{*}{$30{ }^{\circ} \mathrm{C}$} & 76 & 237 & 165 \\
\hline $\begin{array}{l}\text { Accumulated } \\
\text { strain }\end{array}$ & & 3030 & 4368 & 5827 \\
\hline $\begin{array}{l}\text { Creep stiffness } \\
\text { (Mpa) }\end{array}$ & \multirow{2}{*}{$40{ }^{\circ} \mathrm{C}$} & 134 & 270 & 220 \\
\hline $\begin{array}{l}\text { Accumulated } \\
\text { strain }\end{array}$ & & 4273 & 5783 & 6381 \\
\hline $\begin{array}{l}\text { Creep stiffness } \\
\text { (Mpa) }\end{array}$ & \multirow{2}{*}{$50{ }^{\circ} \mathrm{C}$} & 174 & 288 & 247 \\
\hline $\begin{array}{l}\text { Accumulated } \\
\text { strain }\end{array}$ & & 5163 & 6399 & 7945 \\
\hline $\begin{array}{l}\text { Creep stiffness } \\
\text { (Mpa) }\end{array}$ & \multirow{2}{*}{$60{ }^{\circ} \mathrm{C}$} & 228 & 330 & 293 \\
\hline $\begin{array}{l}\text { Accumulated } \\
\text { strain }\end{array}$ & & 5398 & 6748 & 8300 \\
\hline
\end{tabular}

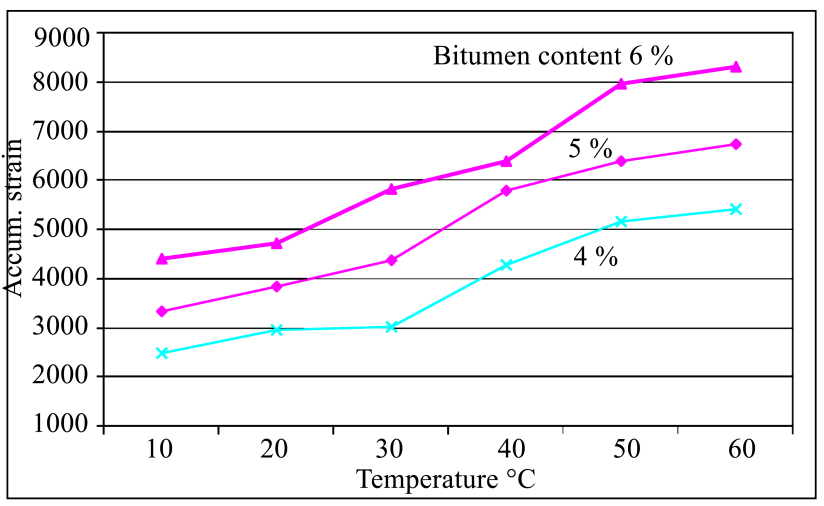

Fig 6. Effect of bitumen content and temperature on accumulated strain $(\mu \varepsilon)$ 


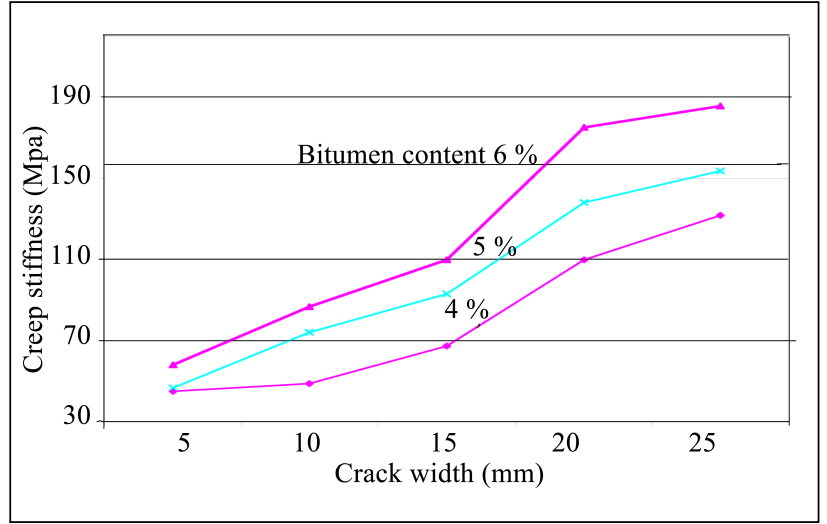

Fig 7. Effect of bitumen content and crack widths on creep stiffness (Mpa)

while a mix with a low bitumen content is more susceptible to fatigue failure especially at low temperatures. In contrast, the laboratory compacted specimens created at the Iran Science and Technology University showed that the mix would behave reasonably well [10]. The maximum permanent deformation is lower in crack sealed asphalt than in cracked asphalt. The study showed that for a mixed asphalt designer crack is significant in permanent deformation (Fig 7).

\section{Conclusions}

Important aspects of material properties relevant to asphalt mix design is performance (creep) characteristics of the mixes. Iranian mixes have not been tested at typical local temperatures to determine their mechanical properties; mix designers have relied on Marshall Property tests.

The results showed that the bituminous mixes had the high creep stiffness at lower temperatures, when using the Marshal design procedure [10].

Designers of bituminous mixes must be cautious in relating dynamic creep test results to performance. The creep test may be more suitable as a method for ranking mixes, rather than as an indicator of rut performance. Bituminous mixes, prepared according to the Iran specifications followed in this research programme, with lower bitumen contents are more resistant to rutting compared to mixes with higher bitumen contents. Even within the range of binder contents allowed by current specifications, binder content must be accurately controlled during preparation of bitu- minous mixes. Mixes with higher bitumen contents were especially more susceptible to rutting, which is determined at a critical temperature of $60{ }^{\circ} \mathrm{C}$ [11].

Further research and tests on a wider range of aggregates are necessary to provide for the great diversity of materials found in Iran.

\section{References}

1. BROWN, E. R. and FOO, K. Y. Comparison of unconfined and confined creep tests for hot mix asphalt. Materials in Civil Engineering Journal, 2004, Vol 6, № 2.

2. BUTTON, J. W.; PERDOMO, D. and LYTTON, R. L. Influence of aggregate on rutting in asphalt concrete pavement. Transportation Research Record, 1999, 1259, p. 141-152.

3. BROCK, J. D.; COLLINS, R. and LYNN, C. Performance Related Testing with the Asphalt Pavement Analyzer. Pavement Technologies, Inc., Technical Paper T-137, Conyers, GA, USA, 2003. $12 \mathrm{p}$.

4. BUTTON, J. W.; PERDOMO, D. and LYTTON, R. L. Influence of Aggregate on Rutting in Asphalt Concrete Pavements. Transportation Research Record, 1999, 1259, p. 141-152.

5. HUGHES, Charles S. Experimental Mixes to Minimize Rutting. ASCE. Boston Society of Civil Engineers Section Journal, Boston, 2004, p. 931-942.

6. MATTHEWS, J. M. and MONISMITH, C. L. Effects of Aggregate Gradation on the Creep Response of Asphalt Mixtures and Pavement Rutting Estimates. ASTM Special Technical Publication, No 1147, ASTM, Philadelphia, PA, 2003, p. 329-343.

7. OWNBY, E. A. Evaluation of Laboratory Compaction of Hot Mix Asphalt. A thesis presented for the Master of Science Degree, the University of Tennessee, Knoxville, TN, 1998.

8. PARKER, F. and BROWN, R. E. Effects of aggregate properties on flexible pavement rutting in Alabama. ASTM Special Technical Publication, No 1147, ASTM, Philadelphia, PA, 2004, p. 68-89.

9. ROBERTS, F. L.; KANDHAL, P. S.; BROWN, R. E.; LEE, D. Y. and KENNEDY, T. W. Hot Mix Asphalt Materials, Mixture Design, and Construction. Second Edition, NAPA Education Foundation, Lanham Maryland, 1998.

10. ZIARI, H.; AMERI, M. and KHABIRI, M. M. Barasi Shiar Shodegi Asfalt Dr Sharaiet Ab Va Havaii Iran. In Proceedings of Second Civil Engineering Conference, Iran, 2005, p. 240-248 (in Persian).

11. KHABIRI, M. M. Development of a mathematical model for increasing flexible pavement life cycle under preventive maintenance. 1th Report of PhD. Thesis. Iran Science and Technology University, 2006.

\section{KARŠTO IR SUPLEIŠĖJUSIO ASFALTBETONIO TAMPRUMAS VEIKIANT KARTOTINEI APKROVAI}

\section{H. Ziari, M. Ameri, M. M.Khabiri}

Santrauka

Bitumo mišiniai tampa vis svarbesni kelių statyboje. Kelių tiesėjai nustatė, jog didžiausia problema yra provėžos karštoje kelio dangoje. Asfalto mišinio užpildų ir rišamosios medžiagos savybių įtaką ilgalaikèms deformacijoms tiksliai vertina Maršalo metodas, tačiau šiuo metu nèra jokio laboratorinio testo, kuris operatyviai nustatytų ilgalaikes karšto betono mišinio deformacines savybes. 
Pagrindinis šio straipsnio tikslas - suteikti informaciją apie laboratorinius bandinius mišinių gamintojams ir kelininkams. Taigi čia aprašyti atlikti testai ir gauti rezultatai. Bitumo kiekio mišinyje ir temperatūros įtakos ilgalaikems asfalto dangos deformacijoms tirti panaudota laboratorinè iranga. Bandant suvokti supleišẻjusios dangos elgseną Irano sąlygomis, nagrinètos dvi supleišẻjusio asfaltbetonio tamprumo charakteristikos, keičiant temperatūrą ir apkrovimo trukmę.

Reikšminiai žodžiai: ilgalaike deformacija, Maršalo metodas, karšto asfalto mišinys, provėžos, itempis, pleišèjimas.

Hassan ZIARI. Assistant professor of engineering (2001) in the college of Civil Engineering at the Science and Technology University of Iran. Member of Iranian pavement association, member of Editorial board of Traffic Journal in Iran. Member of traffic Committee of Civil Engineering association. His research interests include the behaviour of hot asphalt pavement, pavement mix design, concrete mix design, road engineering.

Mahmud AMERI. Associated Professor of engineering (2004) in the Road and Transport Research Centre of Iran Road and Transport Ministry. Head of Iranian pavement association. Member of traffic committee of civil engineering association. His research interests include the maintenance of flexible pavement, pavement mix design, pavement management system, highway engineering.

Mohammad Mahdi KHABIRI. PhD student (2003) of engineering at the Science and Technology University of Iran and lecturer of civil engineering in Vali-Asr Rafsanjan University. Member of Iranian pavement association and member of traffic committee of civil engineering Association in Yazd. His research interests include the pavement preservation maintenance, hot mix asphalt, and pavement analytical design. 